\title{
MARLOWE, MAY 1593, AND THE 'MUST-HAVE' THEORY OF BIOGRAPHY
}

It is the nature of an hypothesis, when once a man has conceived it, that it assimilates every thing to itself as proper nourishment; and, from the first moment of your begetting it, it generally grows the stronger by every thing you see, hear, read, or understand. This is of great use.

Tristram Shandy

The enduring ability of the name of Christopher Marlowe to generate speculation and controversy regardless of the exiguity of the materials at our disposal never ceases to astonish. The temptation to try to extrapolate Marlowe's artistic intentions not only from his playtexts and poems, but from the little that is known about his dramatic career, continues to lead those who write about his life down blind alleys. This tendency to make use of what I like to describe as the 'must-have' theory of biography, according to which Marlowe must have thought this or must have known that, is widespread. ${ }^{1}$ A few years ago, I attempted to demonstrate how little we know for certain about Marlowe's life. ${ }^{2}$ Since the publication of Constructing Christopher Marlowe in 2000, however, several further attempts to explain what happened in the weeks leading up to Marlowe's death in Deptford on 30 May 1593 have been published. While M.J. Trow and Taliesin Trow suggest that he was simply the victim of an Elizabethan contract killing, ${ }^{3}$ David Riggs insists that Elizabeth I personally gave the order for Marlowe to be murdered. ${ }^{4}$ In the 'Revised Edition' of his conspiracy thesis, The Reckoning: The Murder of Christopher Marlowe, Charles Nicholl follows Professor Riggs in suspecting government complicity 
in Marlowe's death. Abandoning the thesis put forward in the original edition of his book - according to which Marlowe was murdered on the orders of the Earl of Essex as part of the power struggle in which he was engaged with Sir Walter Ralegh-Mr. Nicholl now offers an entirely different conspiracy thesis centring on the activities of Richard Cholmeley, and the contemporaneous investigation into heretical activities. ${ }^{5}$

If the 'Revised Edition' of The Reckoning is a perfect illustration of the extent to which those writing about Marlowe are prepared to massage such evidence as exists in order to expound far-fetched theories, Roy Kendall's continuing investigation into the life of Richard Baines demonstrates how a series of inferences ultimately based on a single, unproven premise can mislead scholars into drawing extensive but unsubstantiated conclusions. Dr Kendall admits that he does not know 'whether Marlowe's death was a conspiracy or a "happy" accident', but he is in no doubt whatsoever not only that Thomas Drury wrote the 'Remembrannces of wordes \& matter againste Ric Cholmeley', but that he personally arranged for 'A note containing the opinion of on[e] Christopher Marly concerning his damnable Judgment of Religion, and scorn of Godes word' (commonly known as the Baines note) to be written, personally delivering it to the Privy Council. In turn, according to Dr Kendall, the members of the Privy Council 'knew that something of this nature was on its way via Drury—indeed had been ordered ${ }^{6}$ The problem is that, in each instance, instead of proving his case, Dr Kendall offers inferences which might, at best, be considered to constitute circumstantial evidence.

I have similar reservations about the most recent biography of Marlowe, Park Honan's Christopher Marlowe: Poet \& Spy (2005). ${ }^{7}$ While he tendentiously insists that there are 'surprisingly many ... known biographical facts about Marlowe', Professor 
Honan also patently subscribes to the 'must-have' theory of biography, despite an apparent preference for the formulations 'may have' and 'would have'. He admits that he 'draw[s] modest inferences about personal relationships', maintaining that such a procedure is 'incumbent upon a biographer'. Unfortunately, despite his claim that 'the details in [his] book are factual and true', inferences, in Professor Honan's hands, quickly turn into established facts. Thus, although no evidence is adduced to support the assertion, he writes that 'there is reason to think that [Marlowe] had made contact with a petty functionary or minor secretary in the government, and had begun secret work: this began well before he took the magistratus'. Professor Honan then proceeds, as if it were now a proven fact, to write a chapter of some fifty pages entitled 'Into espionage', in which he refers from time to time to the sort of 'secret work' Marlowe might have undertaken while a student at Cambridge. ${ }^{8}$

Appearing in the midst of the run of biographical studies already mentioned, Constance Brown Kuriyama's Christopher Marlowe: A Renaissance Life (2002) is a very different sort of study. Although she, too, ends up offering what she calls 'reasonable speculation, ${ }^{9}$ she renders sterling service to Marlowe studies by pooh-poohing some of the more preposterous speculations about his (unknown) activities, especially in relation to Gabriel Harvey's 'goggle-eyed sonnet' and the Drury letter. On its own, however, Professor Kuriyama's biography is unlikely to prove sufficient to counterbalance the accumulated weight of guesswork and inference brought to bear in recent years. For this reason I propose to review, once again, the 'evidence' put forward by the various biographers and conspiracy theorists in order to assess the extent to which their accounts of the events of May 1593, insofar as they relate to Marlowe, can reasonably be said to be 
documented, as opposed to merely constituting additional examples of the 'must-have' theory of biography at work.

As comparatively little new information about Marlowe and his milieu has come to light since the Second World War, it is perhaps understandable that, despite the ingenuity of recent commentators, the conclusions of those who first wrote about the discoveries which were made in the 1920s and 1930s have not yet been thoroughly superseded. Accounts of Marlowe's death are disproportionately conditioned by the import of the famous Privy Council certificate, therefore it is necessary to go back as far as his final months at Cambridge in order to review the multifarious hypotheses about the events of May 1593. Over seventy years ago, C. F. Tucker Brooke made two important points in relation to Marlowe's supplicat for his M.A.: "After the granting of the "grace" for the M.A.', he wrote, 'there was no reason for Marlowe to remain at Cambridge, and he eventually did not do so, though it would be necessary for him to return at the July commencement in order to receive the degree that he had earned'; secondly, and perhaps of even more significance, 'whatever unjust suspicion of Marlowe existed at Cambridge would appear to have arisen after his departure from the University, for on 31 March [1587] he seems to have been in perfectly good standing, ${ }^{10}$

While Tucker Brooke's reasoning remains perfectly sound, writers on Marlowe have preferred instead to draw attention to the payments he received from his Parker scholarship during the Lent term of 1587 . According to the Corpus Christi scholarship accounts, these totalled $5 s 6 d$ between 1 January and 25 March $1587 .{ }^{11}$ 'Thereafter his name disappears entirely', John Bakeless remarks. 'Marlowe, no longer a student, is off 
to secret service, London, and the theatre'. ${ }^{12}$ Although one has become accustomed, over the years, to this sort of sloppy scholarship, offhand comments such as these still exert undue influence on the way writers approach Marlowe's life. In the first place, it is simply not safe to assume that the Privy Council certificate is evidence of Marlowe's participation in government intelligence gathering. What the document actually says is that 'Christopher Morley' had been employed in unspecified 'matters touching the benefitt of his Countrie'. ${ }^{13}$ The professed purpose of the communication was to rectify a potential injustice. As Marlowe had been 'defamed by those that are ignorant in th'affaires he went about', he was, as a consequence, in danger of not being awarded his M.A. degree at the July commencement. It was for this reason that their lordships 'thought good to certefie ... that in all his accions he had behaved him selfe orderlie and discreetelie, wherebie he had done her Majestie good service and deserved to be rewarded for his faithfull dealinge ... and that he should be furthered in the degree he was to take this next Commencement'.

There is nothing difficult about any of this; it is perfectly straightforward. The reason that people have jumped to the conclusion that Marlowe was a 'spy' on the basis of the Privy Council certificate is actually on account of the very 'rumor' it was intended to scotch, and which the Privy Councillors were seeking to allay 'by all possible meanes': 'Whereas it was reported that Christopher Morley was determined to have gone beyond the seas to Reames and there to remaine, their Lordships thought good to certefie that he had no such intent'. There is no evidence that Marlowe ever went to Rheims, or that he even left the country in 1587 . We are just as 'ignorant in th'affaires he went about' as his Cambridge contemporaries, and every bit as assiduous in spreading unsubstantiated 
reports on the basis of - what? - the evidence of the 'Audits \&c. 1575 to 90' and the buttery books preserved at Corpus Christi, the putative portrait discovered in a skip of builders' rubble in 1953, and, above all, the Privy Council certificate.

For if it were not for this document, there would be little reason to describe Marlowe as 'a spy'. ${ }^{14}$ As Professor Kuriyama observes: 'While we might like to imagine that Marlowe was involved in some glamorous game of espionage, in fact this is rather unlikely'. ${ }^{15}$ Let me consider, yet again, the burden of the rumour that the Privy Council certificate sought to discredit. The clear suggestion is that a report had been circulating around Cambridge to the effect that Marlowe, having been admitted to the candidacy for his M.A., had absconded to Rheims, 'there to remaine'. Why would he do that? Charles Nicholl observes that 'in the 1580 s going to Rheims meant one thing and one thing only. It meant turning your back on Queen and Country, and enlisting in the Catholic struggle against the established church and government. It meant, in a word, defection' ${ }^{16}$

According to the Privy Council certificate, however, Marlowe did not defect. On the contrary, he had been 'emploied ... in matters touching the benefitt of his Countrie'. Let me re-examine, for the sake of argument, the hypothesis that Mr. Nicholl is eager to propound: 'On the surface Marlowe appears to be a Catholic sympathiser, but this is only a pose. In reality he is the government's man, working in some way against the Catholics. This is the only possible interpretation of the Council's wording'. ${ }^{17}$ This interpretation assumes that, despite the wording of the Privy Council certificate, and in the absence of one iota of corroborative evidence dating from 1587 or earlier, there is substance to the report that Marlowe had expressed the intention of converting to Roman Catholicism, even if it were no more than 'a pose'. Thus the assumption made by his contemporaries at 
Cambridge, including, one assumes, the University authorities themselves, that he had travelled, or was about to travel, to Rheims.

If this were simply a pose, however, what purpose was it meant to serve? Those commentators who believe that Marlowe actually did go to Rheims, presumably in order to attempt to infiltrate the Jesuit seminary there, need to explain several things. First, given the date of the Privy Council certificate, precisely when is Marlowe supposed to have absconded? If Marlowe's putative activities on behalf of the Elizabethan intelligence service took place during one of his apparent absences from the University, then why, given that on each occasion he returned to Cambridge, would it be assumed that he had 'gone beyond the seas to Reames and there to remaine'? When considering an earlier romantic notion that he might have served in the Low Countries during his years as a student at Cambridge—where, doubtless, he met up with Sir Philip Sidney—G.C. Moore Smith, who first made use of the scholarship accounts, doubted if Marlowe could 'have found time ... in any of the years for which we have information, though we may, if we like, imagine him to have taken a term or two off for the purpose in the year 1585-6 of which we know nothing'. 'This however', he concludes, 'is unlikely'. ${ }^{18}$ Moore Smith's scepticism is borne out by Professor Kuriyama's more recent researches. As there are in fact records for every year that Marlowe was at Cambridge, either in the "Audits \&c. 1575 to $90^{\prime}$ or the buttery books preserved at Corpus Christi, it is possible to be more certain about his activities. '[I]f Marlowe's records are compared to those of other students at Cambridge, his patterns of attendance do not appear to be exceptional, and one of his long absences was demonstrably spent visiting his family in Canterbury', Professor Kuriyama sensibly remarks. 'In this case, consideration of a broader range of 
evidence points to a less exciting but far more likely conclusion: Marlowe spent most of his absences from Cambridge doing the same things that other students were doing'. ${ }^{19}$

It appears that if Marlowe did go to Rheims on government service, then the most likely period for him to have done so was between 31 March and 29 June 1587. As I have insinuated, the reasons for this are straightforward: first, Marlowe's absences from Cambridge do not appear to have been out of line with those of other students; second, in that he patently did not do so, the suggestion that, prior to 1587, Marlowe had 'gone beyond the seas to Reames and there to remaine' is simply unfounded; and third, there is no indication that Marlowe was in bad odour with the University or College authorities when he made his supplicat for the granting of his M.A. Yet Professor Kuriyama points out that the surviving papers of the seminary at Rheims 'show no trace of a Christopher Marlowe arriving there in $1587,{ }^{20}$

This is a circumstance which is unlikely to worry the conspiracy theorists, however, for of course Marlowe must have travelled under an assumed name. Thus, maintaining that Walsingham 'almost certainly employed Christopher Marlowe' as early as 1585, M.J. and Taliesin Trow simply assert that ' $[t]$ here is little doubt that he went to Rheims and perhaps elsewhere on Walsingham's business and that this explains at least sixteen months' absences from Cambridge in the period 1580 to 1587 , excluding a year (1585-6) for which there are no records' ${ }^{21}$ Given that there is no documentary evidence to bring to bear on the matter other than the Privy Council certificate itself, there is surely every reason to doubt. Innocent of evidence or argument to support their assertions,${ }^{22}$ the Trows fail to address what appears to me to be the most insuperable obstacle to the thesis that Marlowe went to Rheims on government business: if the plan was that he would 
pretend to be a convert to Catholicism in order to infiltrate the Jesuit seminary 'and there to remaine'-what modern spy fiction writers like Le Carré would describe as the mission of a penetration agent—-then quite clearly he was unsuccessful.

The Privy Council certificate would appear to be unimpeachable evidence that Marlowe was not in Rheims at the end of June 1587. If my reasoning is accepted, then we are left with several possible interpretations of what the document actually imports. Either Marlowe's mission to Rheims was aborted or he went to Rheims on different business, or, if Rheims was not his intended destination, then presumably he was employed on unspecified government business elsewhere. Professor Kuriyama notes that 'Marlowe was well qualified to be a messenger or letter carrier, and this is probably exactly what he was asked to do. ${ }^{23}$ It has even been proposed that, 'judging from the Council's certificate', Marlowe did not leave Cambridge at all but was used to snoop on Catholic cells within the University itself. ${ }^{24}$ What does not appear to have been taken into account is the likely effect of the Privy Council certificate's very existence on the future value of Marlowe as an intelligence agent, which would appear irrevocably to have compromised his future usefulness as an 'undercover' agent. Unless a very long game indeed was being played, Marlowe's putative career as a 'spy' was probably at an end before it had even begun.

The suggestion that Marlowe being used to infiltrate the tight-knit community of Catholic sympathizers in Cambridge is, however, only one of a number of unsupported assertions that Charles Nicholl contrives to make about Marlowe's connections with the intelligence community. As well as envisaging him 'moving among these potential defectors to Rheims', Mr. Nicholl suggests that '[t]he general context of the poet as a 
"household spy" offers a new understanding of Marlowe's government service in the 1580s, and how it might relate to the circumstances of his death'. In the absence of documentary evidence, what is the basis of Mr. Nicholl's speculation? Quite simply, his 'new understanding of Marlowe's government service' is inferred from the 'well-known' fact that 'Walsingham had agents placed in key households' ${ }^{25}$ Perhaps Thomas Watson served in such a capacity. And if he did, then perhaps Marlowe did also. Thus Mr. Nicholl simply transfers his speculations about Watson's putative activities on to Marlowe operating within the household of the Earl of Northumberland. 'We have no direct evidence of Marlowe's involvement with Northumberland before the early 1590s', Mr. Nicholl concedes, 'but it is certainly possible this brilliant young poet had attracted himself to the Earl at this earlier stage, and that part of the "good service" which earned the gratitude of the Privy Council in 1587 was his work as a government tale-bearer within the Northumberland retinue'. ${ }^{26}$

Well, anything's possible. The problem is that not only is there no evidence that Marlowe was attached to the Northumberland household while still a student at Cambridge, the only evidence to link him with Northumberland at all is Sir Robert Sidney's 1592 letter to Burghley from Flushing in which Sidney reports that the 'scholer' he had taken up for 'uttering' a Dutch shilling 'sais himself to be very wel known both to the Earle of Northumberland and my Lord Strang[e]'. ${ }^{27}$ There is not one jot of corroborative evidence that Marlowe was actually 'very wel known' to Northumberland. All we have is this piece of second-hand information. It seems to me to be an immense leap of faith to assume, on the basis of the reported speech of a man caught committing what was, in England, a capital offence, that the government service Marlowe performed 
while at Cambridge in the 1580s was to act as a spy in the household of the 'Wizard' Earl of Northumberland.

Instead of assuming on the basis of the Privy Council certificate that Marlowe was employed as a 'penetration agent' at Rheims or a 'poet-spy' in the household of Northumberland, we should keep in view what it sought to achieve. Its intention was not merely to scotch the rumour that Marlowe had absconded to Rheims, but more importantly to ensure that his M.A. was conferred at the July commencement. While the University authorities had apparently been concerned about Marlowe's activities, we simply do not know what he was doing between 31 March and 29 June 1587 except that he seems to have been employed in the government's service and the Privy Council wished him to be rewarded for his 'faithfull dealing'. According to the supplicat for his M.A., Marlowe had fulfilled the requirements for his degree, and another Parker scholar had been elected to replace him. ${ }^{28}$ On what grounds, then, could he have been prevented from taking his M.A.?

Speculating on such matters, Peter Roberts has recently drawn attention to the residential requirements obtaining at Cambridge in Marlowe's day, according to which students were not required to be in residence for the full nine terms between their taking their B.A. and M.A. degrees, provided that they could satisfy the Vice-Chancellor that they had 'lived soberly and studiously the course of a scholar's life'. On this view, the Privy Council certificate 'was presumably a substitute for the landlord/parson certificate' ${ }^{29}$ True, Marlowe's supplicat states that although he has attended lectures during the nine terms since the final disputation for his B.A., he has not attended them all, as is allowed by the statute ('licet non omnino secundum formam statuti'). ${ }^{30}$ There is, 
however, no suggestion that a 'landlord/parson certificate' is required. Roberts also refers to 'Statute XVI obligating the Fellows of the college to assume holy orders within three years of their admission' to their B.A. degree. It has long been accepted that Marlowe's holding his Parker scholarship for the maximum permitted term implied that he would take holy orders. ${ }^{31}$ Would Statute XVI have applied to Marlowe? If it transpired after 31 March 1587 that Marlowe was not going to take holy orders after all, then this might account for the apparent change of heart on the part of the University or College authorities which made the intervention of the Privy Council necessary.

In the light of Sir Robert Sidney's letter to Burghley dated 26 January 1591 [old style, i.e. 1592], one final issue raised by Peter Roberts which might have a bearing on the matter is worth considering. According to Sidney, 'Christopher Marly by his profession a scholer', and 'one Ri: Baines', each accused the other 'of intent to goe to the Ennemy or to Rome, both as they say of malice one to another'. Now we know for a fact that $a$ Richard Baines did go to the seminary at Rheims in 1578, and that he wrote a sort of confession outlining his errors. ${ }^{32}$ Around the time that Marlowe matriculated at Corpus Christi in 1581, Father Robert Parsons, SJ, informed the General of the Society of Jesus that he had infiltrated a Roman Catholic priest into the University at Cambridge 'in the guise of a scholar or gentleman commoner' with the purpose of converting 'very fit youths' and sending them to the English College at Rheims. Peter Roberts wonders whether the Privy Council certificate 'might have been intended to exculpate Marlowe from suspicion of being one such "fit youth", 33 
The name of Richard Baines was of course well-known to Marlowe scholars prior to the publication of Sir Robert Sidney's letter to Burghley on account of the notorious 'Baines note' preserved in manuscript in the British Library which is headed: 'A note containing the opinion of on[e] Christopher Marly concerning his damnable Judgment of Religion, and scorn of Godes word' ${ }^{34}$ If interpretation of what happened to Marlowe during May 1593 is conditioned by our assumptions about his activities as a government agent, it is also conditioned by documents written after his death. These include Thomas Kyd's undated letters to Sir John Puckering, the Lord Keeper, ${ }^{35}$ the mysterious 'Copy ${ }^{\mathrm{e}}$ of Marlowes blasphemyes as sent to her H., ${ }^{36}$ and Thomas Drury's letter to Anthony Bacon. ${ }^{37}$ I shall consider each of these documents in turn, as well as taking into account the undated 'Remembrannces of wordes \& matters against Ric Cholmely'. ${ }^{38}$

Recent discussions of the events of May 1593 tend to be outrageously Marlowecentric. ${ }^{39}$ Take, for instance, Charles Nicholl's comment on the apprehension of Thomas Kyd. 'If the purpose of arresting Kyd was to incriminate Marlowe - and there seems little other reason for this erroneous, puzzling arrest—-then the finding of the Arian tract accomplishes that purpose ${ }^{40}$ Given that Kyd flatly contradicts this putative version of events, it is odd that such an argument should be put forward. Towards the end of his undated letter to Puckering, Kyd mentions 'the Libel laide unto my chardg' [sic]. ${ }^{41}$ To what, precisely, was Kyd referring? Crucially, the account offered by Kyd not only attempts to establish the provenance of the 'Arian tract' to which Mr. Nicholl alludes, it supplies a clear indication of the context of his arrest. Earlier in his letter to Puckering, Kyd writes: 
When I was first suspected for that Libell that concern'd the state, amongst those waste and idle papers ( $w^{\text {ch }}$ I carde not for) $\& w^{\text {ch }}$ unaskt I did deliver up, were founde some fragments of a disputation, toching that opinion, affirmd by Marlowe to be his, and shufled $\mathrm{w}^{\text {th }}$ some of myne (unknown to me) by some occasion of $\mathrm{o}^{\mathrm{r}}$ wrytinge in one chamber two yeares synce. ${ }^{42}$

This crucial passage offers essential evidence on a number of counts. First, it links Kyd's arrest to a 'Libell that concern'd the state'. Kyd was taken into custody immediately after a letter dated 11 May 1593 had been sent from the Privy Council 'to Sir R. Martin, Anthony Ashley, Mr. Alderman Buckle, \&c.' which reads:

There hath been of late divers lewd and malicious libels set up within the city of London, among the which there is some set upon the wall of the Dutch Churchyard that doth exceed the rest in lewdness; and for the discovery of the author and publisher thereof her Majesty's pleasure is that some extraordinary pains and care be taken by the commissioners appointed by the Lord Mayor for th' examining such persons as may be in this case any way suspected. These shall be, therefore, to require and authorize you to make search and apprehend every person so to be suspected, and for that purpose to enter into all houses and places where any such may be remaining. And, upon their apprehension, to make like search in any of the chambers, studies, chests, or other like places for all manner of writings or papers that may give you light for the discovery of the libelers. And after you shall have examined the persons, if you shall find them duly to be suspected, and they shall refuse to confess the truth, you shall by authority hereof put them to the torture in Bridewell, and by th' extremity thereof, to be used at 
such times and as often as you shall think fit, draw them to discover their knowledge concerning the said libels. We pray you herein to use your uttermost travail and endeavour, to th' end the author of these seditious libels may be known, and they punished according to their deserts. And this shall be your sufficient warrant. ${ }^{43}$

Given what he wrote to Puckering not only about a libel 'that concern'd the state', but about 'some fragments of a disputation, toching that opinion, affirmd by Marlowe to be his', it seems perverse to argue that Kyd was arrested in order to incriminate Marlowe. The Privy Council letter specifically required the commissioners appointed by the Lord Mayor of London not only to apprehend the usual suspects, but to search 'for all manner of writings or papers', and to question them about whatever they might find. In the circumstances, there appears no reason to assume that the arrest and examination of Kyd did not follow the course outlined in the Privy Council letter, down to his being put to the torture.

Kyd, then, was taken up in connection with the various libels, including the Dutch Church libel, which had been posted around London in the weeks leading up to 11 May 1593. His apprehension prompts a number of questions. First, why should Kyd have been suspected of involvement in the production of 'the said libels'? Charles Nicholl's speculations are based on the facts that the Dutch Church libel was signed 'Tamberlaine' [sic], and that Kyd informed Puckering of the origins of his 'acquaintance $\mathrm{w}^{\text {th }}$ this Marlowe' ${ }^{44}$ As such, they offer an especially fine example of the way in which interpretation of the events of May 1593 can be conditioned by a document written after Marlowe's death. Although I am unaware of any documentary evidence to suggest that, 
prior to his interrogation, Kyd was known to be linked with Marlowe, Mr. Nicholl suggests that the fact that he was a "fellow playwright and "familiar friend" of Marlowe's' was 'perhaps ... enough to put the unfortunate Kyd in the frame as "Tamburlaine": a panicky, literal-minded arrest". 45

There are problems with this interpretation other than its assumption that Kyd 'was a known associate of Marlowe's'. Extravagantly Marlowecentric, it jumps to the conclusion that any reference to 'Tamburlaine' would have been construed by contemporaries as a reference to Marlowe. Although the Dutch Church libel was signed 'Tamberlaine', it would seem reasonable to ask whether Marlowe would have been known by contemporaries as the author of the play of that name. Leaving to one side the large question of whether playgoers would have recognized the names of any of the playwrights whose plays they flocked to see at the Rose, no contemporary documentary evidence exists to link Marlowe with Tamburlaine other than Robert Greene's reference in Perimedes the Blacke-Smith to 'such mad and scoffing poets, that haue propheticall spirits as bred of Merlins race'. The relevant passage begins by mentioning 'two Gentlemen Poets' who have 'latelye' appeared 'vpon the stage in tragicall buskins', and goes on to accuse them of 'daring God out of heauen with that Atheist Tamburlan'. As 'Merlin' would have sounded like 'Marlin' in Elizabethan England, and as Marlowe's name appears as 'Marlin' in numerous instances in the records preserved at Corpus Christi, the suggestion is that Greene is here obliquely attributing Tamburlaine to Marlowe. It is for this reason, one assumes, that Stanley Wells regards the passage from Perimedes as providing 'the principal external evidence for the date and authorship of the play'. 46 
Persuasive as this argument is for the attribution of Tamburlaine to Marlowe, it is scarcely indicative of his authorship being common knowledge. First, it would have required contemporaries to have recognized that Greene was playing on Marlowe's name when he referred to 'such mad and scoffing poets, that haue propheticall spirits as bred of Merlins race'. Second, it offers no solution to the vexed question of the identity of the 'two Gentlemen Poets', or their relationship with Marlowe or his play. Finally, it requires an immense leap of logic to suggest that the Dutch Church libel was signed 'Tamberlaine' in order to implicate Marlowe. Yet that is what has been suggested. Thus Curtis C. Breight argues that: 'It is clear that the Dutch Church libel was cooked up to render Marlowe as a source of subversive thought against the state, since it alludes to his plays and bears a kind of signature ${ }^{47}$ Yet if we turn to the Dutch Church libel itself, as printed by Arthur Freeman, it is disconcerting to find that these alleged allusions to Marlowe's plays consist of the line 'Your Machiavellian Marchant spoyles the state', the couplet 'Not paris massacre so much blood did spill/ As we will doe iust vengeance to you all', and of course the marginal 'signature' at the end: 'per Tam-berlaine'. ${ }^{48}$

We now know of course that not all contemporary allusions to 'Tamburlaine' refer to Marlowe. Despite the striking opening line 'Weepe Powles, thy Tamberlaine [sic] voutsafes to dye', it has been convincingly demonstrated that Gabriel Harvey's 'goggleeyed sonnet', which was long taken as an allusion to Marlowe's death, actually refers to the death in September 1593 of the eccentric Peter Shakerley. This is used by Harvey as an occasion to lambast Thomas Nashe, who is cuttingly described as 'the second Shakerley of Powles'. Charles Nicholl takes considerable pains to explain how the misidentification came about, ${ }^{49}$ yet he seems reluctant to reconsider any other apparent 
allusions to Marlowe in the extant documentary evidence from the same year. What Harvey's A New Letter of Notable Contents, With a straunge Sonet, intituled Gorgon, Or the wonderfull yeare clearly indicates, however, is that, even after the furore occasioned by the 'divers lewd and malicious libels set up within the city of London', including the Dutch Church libel, contemporary references to 'Tamburlaine' or 'Tamberlaine' were not necessarily code for Christopher Marlowe.

What we appear to be left with, then, are unsubstantiated assertions that Kyd 'was a known associate of Marlowe's' at the time of his arrest, that 'the purpose of arresting Kyd was to incriminate Marlowe', and that the mere use of the name 'Tamburlaine' would automatically have been assumed by contemporaries to refer to Marlowe. Against these assertions should be set the documentary evidence contained in Kyd's letters to Puckering, which strongly suggests that he was taken up because he was suspected, rightly or wrongly, of complicity in the production a 'Libell that concern'd the state', that fragments of The Fal of the Late Arrian were found among his 'waste and idle papers', and that he shuffled responsibility for these papers - which were in fact part of a treatise published by John Proctor in 1649—on to Marlowe as a consequence of their 'wrytinge in one chamber two yeares synce'. As Ethel Seaton sensibly concluded seventy-five years ago: 'Kyd, arrested on suspicion of libels, became involved in a charge of atheism, and shook it off on Marlowe, all the more vigorously because Marlowe had in the meantime been killed on Wednesday, May 30, 1593, ${ }^{50}$ On this view, there is no need to assume that the Dutch Church libel was a 'fake' written by Richard Cholmeley with the sole purpose of getting Marlowe into trouble, or that the fragments found in Kyd's possession were planted there in order to incriminate Marlowe. ${ }^{51}$ 
As the Privy Council had specifically ordered 'th' examining such persons as may be in this case any way suspected', the fact that, under duress, Kyd had implicated Marlowe could not simply be discounted or ignored. After appearing before the Privy Council on 20 May, however, Marlowe was released on bail and 'commanded to give his daily attendance to their lordships, until he shall be licensed to the contrary'. This strongly suggests that he was not a prime suspect, let alone that the whole exercise had been orchestrated with his disgrace and downfall in mind. On the contrary, it would appear to indicate that Marlowe had not been suspected of any involvement in the production of libels that concerned the state until after Kyd had been arrested and tortured. And after Marlowe's death on 30 May 1593, of course, Kyd could shift any blame on to him with impunity. It is for this reason, perhaps, that underneath the endorsement '12 May 1593 Vile hereticall conceiptes denyinge the deity of Jhesus Christ our Saviour fownd amongst the papers of Thos Kydd prisoner' made on the document preserved in the British Library is a further endorsement, in the same hand, but in a different ink: ' $\mathrm{w}$ ch he affirmeth that he had from Marlowe'. ${ }^{52}$

However, Kyd's letters to Puckering were not the only documents dating from after Marlowe's death which apparently sought to discredit him by drawing attention to his 'monstruous opinions'. Two versions of a curious manuscript signed 'Richard Baines' are extant in the British Library, one of them in fact preserved in the same volume of documents as Kyd's undated letter to Puckering. Presumably this is the same Richard Baines who, out of 'malice', accused Marlowe 'of intent to goe to the Ennemy or to Rome' on being arrested for coining in Flushing in January $1592 .{ }^{53}$ This is an important consideration, because it strongly suggests that 'A note containing the opinion of on[e] 
Christopher Marly concerning his damnable Judgment of Religion, and scorn of Godes word ${ }^{54}$ was hardly a disinterested statement of Marlowe's heterodox opinions. On the contrary, as one of the opinions imputed to Marlowe was

That he had as good right to coine as the Queen of England and that he was acquainted with one Poole a prisoner in Newgate who hath greate skill in mixture of mettals and having learned some thinges of him he ment through help of a cuning stamp maker to coin French crownes, pistoletes and English shillinges it would appear that there are good grounds for assuming that the note consisted largely of an amplification of the sort of allegations about Marlowe that Baines had made to Robert Sidney almost eighteen months earlier. ${ }^{55}$

Charles Nicholl, therefore, is quite right to observe of the Baines note that ' $[t]$ his document, which has perplexed and scandalised Marlowe's biographers for centuries, tells us nothing for certain except that Richard Baines wished to accuse Marlowe of heresy' ${ }^{56}$ Why, then, were two distinct versions made of Baines's allegations, and why, in particular, was the form of words used to introduce 'Marlowes blasphemyes' markedly different? A series of emendations in each offers clear evidence of uncertainty about how the documents should be headed. What is obviously the earlier version is simply called 'A note containing the opinion of on[e] Christopher Marly concerning his damnable epini Judgment of Regligion, and scorn of Godes word' ${ }^{57}$ In the second version this heading is heavily scored through and revised to read 'A note of the most horrible blasphemes and Damnable opinions uttered by Xpofer Marly who w[i]thin iii d[a]yes after came to a sudden $\&$ fearfull end of his life ${ }^{58}$ The changes do not end there, however. In the top left-hand margin of the later version the following words have been inserted at the 
beginning of the document: 'A note delivered on whitsun eve last of the' [sic]. And it is this version which is also endorsed 'Copy ${ }^{\mathrm{e}}$ of Marlowes blasphemyes as sent to her H.'

Of the many questions raised by these documents, the following seem to me to be most pertinent: 1) why was the heading refined so that it accentuated Marlowe's 'most horrible blasphemes and Damnable opinions'? 2) why was the heading in the later version altered in order to indicate that it was 'delivered on whitsun eve'? 3) why was a copy sent to Elizabeth I?

1) The earlier version of the Baines note includes the following: 'That [illegible] That on Ric Cholmley hath Cholmley hath confesst that he was perswaded by Marloes reasons to become an Atheist'. Professor Kuriyama has suggested that, as these lines 'are cramped', they 'might have been inserted later'. ${ }^{59}$ Interestingly, next to these very lines in the revised version of the Baines note there is another marginal comment, apparently in the same hand as the marginal comment next to the revised heading of the note, stating that 'he is layd for'. The rest of the note is scored through. It appears, then, that steps had been taken to apprehend Richard Cholmeley even before a tidied-up copy of the Baines note had been sent to the Queen. Further, a document headed 'Remembrannces of wordes \& matter againste Ric Cholmeley' is preserved in the same bound volume as the first version of the Baines note.$^{60}$ Significantly, one of the charges laid against Cholmeley is That hee saieth \& verily beleveth that one marlowe is able to shewe more sounde reasons for Atheisme then any devine in Englande is able to geve to prove devinitie \& that marloe tolde him that hee hath read the Atheist lecture to $S^{r}$ walter Raliegh \& others. 
What are we to make of this allegation? That the investigation was being undertaken with the sole or primary aim of discrediting Marlowe? Or that Marlowe's name was being bandied about by worried men who were desperate to avoid the consequences of being charged with atheism?

Despite the various dates which have been put forward, we do not know when the document headed 'Remembrannces of wordes \& matter againste Ric Cholmeley' was written, or by whom. Charles Nicholl's suggestion that the author of the 'Remembrannces' was Thomas Drury has found support from Roy Kendall and David Riggs, ${ }^{61}$ although Professor Kuriyama regards the attribution as 'impossible', not only because of the vast dissimilarity between the two documents in terms of their basic intelligibility, but for the compelling reason that the author of the 'Remembrannces' made great play of the fact that he had had to win the confidence of Cholmeley and his 'dampnable $[s i c]$ crew ... with fair wordes', whereas Drury was known to Cholmeley of old. While she acknowledges that the date of composition is unknown, Professor Kuriyama suggests that the 'Remembrannces' were probably written preceding a warrant for Cholmeley's arrest on 19 March $1593 .{ }^{62}$ On the other hand, the document is endorsed:

$y^{\mathrm{e}}$ atheisme of [Cholmeley] \& others yong taken $\&$ made an instrument to take $\mathrm{y}^{\mathrm{e}}$ rest hariet./ borage dangerous tippinges ii. 
As Ethel Seaton argued as long ago as 1929, this would appear to indicate that the 'Remembrannces' were drafted as part of the general government investigation into subversive activity of May $1593 .^{63}$ 'This cursed Chomeley hath Lx [i.e. sixty] of his company \& hee is seldome from his fellows', a second undated report on Cholmeley advised its unknown addressee, ' $\&$ therefore I beseech your worship have a speciall care of your selfe in apprehendinge him for they bee resolute murderinge myndes'. ${ }^{64}$

It is difficult to judge how seriously to take these warnings. The desperado Cholmeley finally turned himself in to the authorities on 28 June 1593, as Lord Keeper Puckering - the recipient of Thomas Kyd's undated communication — was informed the following day in a letter from Justice Richard Young. According to Young, 'the said Chomley' had been committed to prison 'so that now he is to be examined by such as it shall please your Honours to appoint'. 'And for the rest [of his sect]', Young continued, 'I do not doubt but they will submit themselves now one of the principals be apprehended'. ${ }^{65}$ We do not know what subsequently happened to Cholmeley. Ethel Seaton, however, was convinced that 'all those whom in one way or another we know of as Marlowe's associates in 1593 are interlinked in the conspiratorial ramifications that can be traced from the docket of the Cholmley [sic] papers' preserved in Harleian MS 6848. In marked contrast to Charles Nicholl, Seaton concluded 'that, however indirectly, conspiracy, and not atheism, was the cause of Marlowe's death, whether deservedly or not' ${ }^{66}$ This seventy-five-year-old argument remains persuasive. Regardless of whether they link his killing to his arrest, those commentators who prefer to connect what happened to Marlowe in May 1593 to the contemporary investigation into atheism do so because of the allegations made in the Baines note and the Cholmeley 'Remembrannces'. 
The revised heading of the Baines note gave greater prominence to Marlowe's 'most horrible blasphemes and Damnable opinions' and this, in turn, served to link it with the concurrent government investigation into heretical activities.

2) If this conclusion is correct, then the insistence of the revised version of the Baines note that it was 'delivered on whitsun eve' assumes significance. Marlowe was killed on 30 May 1593. Whit Sunday fell on 2 June. Whoever altered the title of the Baines note to accentuate his 'most horrible blasphemes and Damnable opinions' apparently confused the previous Sunday with Whit Sunday. This, at any rate, would explain why emphasis was placed on Marlowe's supposedly coming 'to a sodden \& fearfull end of his life ... w[i]thin iii d[a]yes' of uttering such dreadful imprecations as were contained in the Baines note. 'Seeing he is taking so much trouble over the title', Charles Nicholl pertinently observes, 'it is curious that the corrector gets the facts wrong ${ }^{67}$ Professor Kuriyama, on the other hand, regards '[s]uch faulty recollection as perfectly understandable, since Whitsunday is a moveable feast ${ }^{98}{ }^{68}$ However, the most striking feature of the revised heading, it seems to me, is that the unidentified corrector took considerable pains to ensure that the impression was given that the Baines note was delivered before, and not after, Marlowe's death. ${ }^{69}$

Why? In order to answer this question, it is, I think, important to note the sequence in which the successive changes to the Baines note were made. Initially, the revised version simply copied the heading of the original, so that it reads: 'A note contayninge the opinion of one Christopher Marlye concernynge his damnable opinion and Judgment of Relygion and scorne of Gods worde'. To this was added the phrase: 'who since Whitsunday dyed a sodden \& violent deathe'. This heading was then scored 
through and replaced by: 'A note of the most horrible blasphemes and Damnable opinions uttered by Xpofer Marly who wthin iii dyes after came to a sudden \& fearfull end of his life'. Finally, the beginning of the revised heading was altered once more to read: 'A note delivered on whitsun eve last of the' $[s i c] .{ }^{70}$ Given the various errors, alterations and corrections, a lingering suspicion remains that the statement which insists that the note was 'delivered on whitsun eve' was simply an insertion made after the event in order to avoid any suggestion that the Baines note was a put-up job formulated after Marlowe's death so that imputations of blasphemy and atheism could conveniently fall upon a dead man.

3) Such a suspicion is supported by the fact that it is this version of the Baines note which is endorsed 'Copy ${ }^{\mathrm{e}}$ of Marlowes blasphemyes as sent to her H.'. Professor Kuriyama suggests that, at some point during the weeks following Marlowe's death, the 'edited copy' of the Baines note 'was made to alert the queen to the atheist menace'. ${ }^{71}$ It was also in these weeks, of course, that Kyd was anxiously attempting to allay Puckering's suspicions 'concerning Atheisme, a deadly thing which I was undeserved charged withall' ${ }^{72}$ Thomas Drury's letter to Anthony Bacon, dated 1 August and assumed to have been written in 1593 , also refers to an investigation into atheistical activities undertaken by Lord Keeper Puckering and Lord Buckhurst. Indeed one of Drury's strongest complaints is that 'ther was by my only means sett dou[n] vnto the Lord Keper [and] the $\mathrm{L}^{\text {rd }}$ of Bucurst the notablyst and vyldist artyckeles of Athemysme [sic] that I svppose the lyke wer never known or red of in eny age', that these articles 'were delivered to her hynes and command geven by her selffe to prosecut it', but that up until that time he had received 'no recompense no not of a penny'. ${ }^{73}$ 
On the basis of this assertion, Charles Nicholl regards the Drury letter as confirmation that the revised copy of the Baines note was sent to the Queen. ${ }^{74}$ Whatever its obscurities, and possible misrepresentations', he argues, 'this letter is a key document, because it provides an insider's eye-view of the atheism investigation' ${ }^{75}$ Given that the obscurities contained in the Drury letter are profound, the certitude with which commentators have interpreted its meaning is astounding. As far as Charles Nicholl is concerned, because Drury 'undoubtedly' alludes to ‘the Lord Mayor's proclamation of 10 May 1593, which offered 100 crowns in gold for information about the authors of the recent libels', it is 'obvious' that the 'desired secret' Drury was charged to get from Baines was 'the identity of the [Dutch Church] libeller', and that Baines named 'the man who I believe really did write the Dutch Church libel: Richard Cholmeley’. Mr. Nicholl goes on to suggest that the references to a 'libel', to 'a vile book', and to 'a notable villain or two' tie in 'very closely with the "Remembrances" against Richard Cholmeley'. 76 While Roy Kendall is prepared to entertain the supposition that 'the desyered secrit' which Drury got from 'on[e] mr Bayns' was the identity of the Dutch Church libeller, he views the substance of his letter to Bacon very differently. Believing that the Baines note was ordered by the Privy Council, and extracted from a reluctant Baines by Thomas Drury, Dr Kendall insists that, "in relation to the command of "her hynes," Drury can only be alluding to the "artyckeles"/Baines Note (delivered, according to the endorsement, on approximately May 27), which, along with the "vyld bocke" and the "lybell," Drury proudly declares were procured and "sett doun vnto the Lord Keper [and] the Lord of Bucurst" by "my only means"'. It is possible, in this way, to link "the notablyst and vyldist artyckeles of Athemysme ... delyvered to her hynes' to the 
mysterious 'Copy ${ }^{\mathrm{e}}$ of Marlowes blasphemyes as sent to her H.'. According to Dr Kendall, Drury's 'declaration' is confirmation of 'what is known of BL, Harl. M 6853, ff. 307-8the Baines Note'- that Queen Elizabeth “"her selfe” commanded that the matter be prosecuted "to the fule". ${ }^{77}$ This chimes in with the thesis put forward in The World of Christopher Marlowe by David Riggs, according to which Drury was ordered 'to procure more intelligence to the case of Christopher Marlowe'. Among the tasks successfully undertaken by Drury, Professor Riggs asserts, was the extraction from Baines of the identity of the Dutch Church libeller, the discovery of an unidentified 'lybell' and 'a vyld bocke', and the obtaining of a transcript of 'the notablyst and vyldist artyckeles of Athemysme' which he has 'little doubt ....are identical to' the Baines note. ${ }^{78}$

Charles Nicholl takes the argument one stage further. By 'the bocke that doeth mayntayn this damnabell sect', he argues, Drury 'presumably means the text of the "atheist lecture" which Marlowe supposedly read to Ralegh'. Mr. Nicholl then uses this assumption to jump to the conclusion that when Drury refers to 'thay to howe it was delyvered as allso who red the lecture and wher and when', 'he doubtless means the Ralegh circle ... to whom the lecture was "delivered"'. This seems to be a further example of the 'must-have' theory of biography at work. Why one should assume that Drury is referring to an 'atheist' lecture written by Marlowe and delivered to the shadowy 'school of night', rather than the manuscript copy of a heretical or 'atheistical' book submitted to a printer for production in order to 'mayntayn' the 'damnabell sect' of which Drury writes, I do not know.

In considering the Drury letter, it is of interest that, once again, the allegations it contains are of course made after Marlowe's death. This is of significance on two counts. 
First, as Professor Kuriyama remarks, '[s]ince Marlowe had been dead over two months and his death was fairly notorious, Drury had no reason to be coy about naming him' ${ }^{79}$ If 'the bocke that doeth mayntayn this damnabell sect' is Marlowe's 'atheist' lecture, then the person who wrote the book was already dead. It therefore seems odd that Drury should set such store by his offer to arrange for Bacon to meet 'the man that doeth know who did wryght the bocke and thay to howe it was delyvered', let alone why he should expect to be rewarded for so doing. Further, if he were indeed claiming credit for the Baines note 'sent to her H.', then Drury, like Baines, Cholmeley and Kyd, could say whatever he liked about Marlowe's 'most horrible blasphemes and Damnable opinions' secure in the knowledge that he could neither be implicated in the activities under investigation nor gainsaid by a dead man.

Finally, what none of these speculations addresses is the large question whether any of the inferences in the Drury letter refers to Marlowe. 'Drury's letter has been the object of considerable speculation', Professor Kuriyama pertinently remarks, 'but it may, like Gabriel Harvey's "goggle-eyed sonnet," actually have nothing to do with Marlowe' ${ }^{80}$ Given the tortuous manner in which Drury expresses himself, it is not easy to determine what he is writing about, let alone to draw firm conclusions from his various references to 'the desyered secrit', 'a lybell', 'a vyld bocke', 'the notablyst and vyldist artyckeles of Athemysme', 'the bocke that doeth mayntayn this damnabell sect', and 'the lecture'. True, Drury tells Bacon that he can show him the 'artyckeles of Athemysme' which were 'by my only means sett dou[n] vnto the Lord Keper [and] the $\mathrm{L}^{\text {rd }}$ of Bucurst', and which 'wer delyvered to her hynes'. This clearly corresponds with the endorsement on the revised version of the Baines note, which reads, 'Copy ${ }^{\mathrm{e}}$ of Marlowes blasphemyes 
as sent to her H.', and this, in turn, is the basis of Professor Riggs' thesis that the Queen herself 'pronounced Christopher Marlowe's death sentence ("prosecute it to the full") at court'. 81

What cannot be demonstrated, however, is that Elizabeth received the 'Copy ${ }^{\mathrm{e}}$ of Marlowes blasphemyes' prior to Marlowe's death at Deptford on 30 May 1593. Indeed, in view of the doubt that exists concerning not only the relationship between the original version of the Baines note and the copy, but about the date on which it was delivered ('on whitsun eve'?), and to whom-doubt which the Drury letter, however it is interpreted, does little to dispel—it is unlikely that either of the documents preserved in the Puckering papers in the British Library was sent to the Queen, for two principal reasons. First, I find it difficult to believe that, after taking all this trouble to find Baines, to extract a note from him accusing Marlowe of various 'blasphemyes', and to revise the note to accentuate the monstrous nature of his offences and the fact that he died three days after the delivery of the note, a clean copy to send to the Queen would not have been transcribed. Second, the two extant versions of the Baines note are preserved not among the Queen's papers, but among the papers of Lord Keeper Puckering. Professor Kuriyama's suspicion that the 'edited copy' of the Baines note 'was made to alert the queen to the atheist menace' after Marlowe's death makes much more sense.

In conclusion, I should like to suggest why this might have been done. If, as the Privy Council letter dated 11 May 1593 suggests, the investigation into atheism began as an investigation into seditious libel after the appearance of the Dutch Church libel, then it was only after the discovery of 'Vile hereticall conceiptes' among Kyd's papers ' $w$ ch he 
affirmeth that he had from Marlowe' that it changed direction, perhaps coalescing with the concurrent investigation into the authorship of the Marprelate tracts. Marlowe became implicated in the investigation because he was named by Kyd. Regardless of whether Roy Kendall is right to believe that the Baines note was ordered and delivered by Thomas Drury, it was certainly produced at a very convenient moment as far as this investigation was concerned. It not only fitted in with Cholmeley's 'Remembrannces' (whenever they had been written and by whom), it was also susceptible of revision and communication to the Queen after Marlowe's death on 30 May 1593. And once he was dead, of course, the potentially damaging consequences of any lingering imputations of atheism could be conveniently laid at Marlowe's door. Thus the care taken in the successive revised headings of the Baines note not only to give the impression that Marlowe had suddenly and providentially been struck down within three days of the delivery of the note 'on whitsun eve', but also to pre-empt any suspicion that it might be an ex post facto fabrication intended to deflect, if not to put an end to, the investigation into atheistical activity itself.

In recent years, a variety of conspiracy theses have been put forward to explain Marlowe's violent death. Marlowe was killed either as the consequence of a power struggle between Sir Walter Ralegh and the Earl of Essex, or because of a power struggle between different groups in the intelligence community. Alternatively Marlowe was set up as the supposed author of the Dutch Church libel, and subsequently killed because of the contemporary investigation into atheistical activities, if not simply because he had personally offended Elizabeth I in some way. What all these conspiracy theses have in common is a reluctance to accept that, as an obscure Elizabethan playwright, Marlowe 
was highly unlikely to have been of sufficient importance to have attracted the attention of powerful men, let alone the Queen herself. Thus the suggestions that the Dutch Church libel was not simply another example of the extensive English xenophobia evident at this time but was 'cooked up' as a deliberate attempt to point the finger of suspicion at Marlowe, or that the purpose of Kyd's arrest and interrogation was to incriminate Marlowe, or that his death warrant was effectively signed the moment the Queen commanded that the investigation into atheism be prosecuted 'to the full', only make sense if it is assumed that he was in some way a serious threat to the stability of the state.

As a hypothesis, this seems to me to be highly unlikely, if for no other reason than that, after ordering Marlowe's apprehension on 18 May, the Privy Council released him two days later on the condition that he would 'give his daily attendance on their lordships, until he shalbe licensed to the contrary'. If Marlowe was such a security risk, then why was he released at all? On the other hand, if Marlowe had simply been set at liberty so that he could be murdered in Deptford as a consequence of the Queen's insistence that (to use Baines's words) 'the mouth of so dangerous a member' should 'be stopped', then it was a decidedly odd way of proceeding. The trial of John Penry began the day after Marlowe was released. Penry was executed on 29 May, the day before Marlowe was killed. It is difficult to believe that judicial murder would not have been less messy to arrange than a contract killing 'within the verge' at Deptford which inevitably implicated figures within the Elizabethan intelligence community.

The assumption that Marlowe must have been killed because of his connections with this community stems from the fact that he rode to his death from Thomas Walsingham's house at Scadbury, and that the men he rode to meet at Deptford had all 
been involved to a greater or lesser extent in intelligence gathering. Robert Poley, indeed, was 'one of Walsingham's most cunning and successful spies', ${ }^{82}$ and he had just returned from The Hague when he met Marlowe at the house of Eleanor Bull. Not only had Poley been involved in the exposure of the Babington plot, Thomas Walsingham had used Poley's house in Bishopsgate to collect messages from his kinsman, Sir Francis Walsingham. In addition, Ingram Frizer was Thomas Walsingham's servant, ${ }^{83}$ and Nicholas Skeres is known to have been an associate of Frizer's. 'Few people now believe that Marlowe was stabbed over a bar tab ("le recknynge")', writes Curtis C. Breight, 'largely because all the figures surrounding Marlowe were shady characters'. He then leaps to a much more satisfying conclusion: 'The killing of Marlowe is connected to some kind of struggle in the surveillance underworld ${ }^{84}$ The principal problem with this, particular 'must-have' line of reasoning is that not only do we have no indication of why Marlowe was killed, the belief that it must have had something to do with conflict within the intelligence community depends entirely upon the fact that the men with whom he spent the day in Deptford on 30 May 1593 were shady characters. Yet, as Professor Kuriyama pertinently remarks, 'Marlowe probably knew all three of these men well and had no reservations about spending a day with them'. ${ }^{85}$

I argued at the outset that our reading of the events of 1593 as they affect Marlowe is conditioned by our assumptions about his previous activities. While to some degree this is natural and unavoidable, the number and extent of the lofty edifices that continue to be erected on these shaky foundations have increased in recent years. Instead of acknowledging that, in the absence of any firm evidence, we just do not know the nature of the 'matters touching the benefitt of his Countrie' in which he was employed 
prior to 27 June 1587, commentators, from Bakeless onwards, have simply assumed that Marlowe was 'off to secret service'. In turn, the temptation to seek the explanation for Marlowe's death in his murky past, in his dealings as an intelligence agent, derives almost entirely from the existence of the Privy Council certificate. Hence the reluctance to accept the verdict brought in by sixteen jurors at the inquest on his death in Deptford. Above all, what has certainly not been proved by any of the recent biographical studies is that Marlowe must have been the target of the government investigations into atheistical and subversive activities which took place in May 1593.

\footnotetext{
${ }^{1}$ A particularly good example occurs in the section of Alan Haynes' book, first published in 1990, but republished in 2000 as The Elizabethan Secret Services, entitled 'Death of a Spy'. Discussing Marlowe's alleged decision to work for the Elizabethan secret service, Haynes writes about 'the employment of the young Marlowe whose contact with the younger Lyly must have been the clinching element in the decision. By accident or design he must have made the acquaintance of covert Catholics within Cambridge University' (A. Haynes, The Elizabethan Secret Services (Stroud, 2000), 109). For Marlowe's assumed attempts to infiltrate Catholic circles at Cambridge, see below, 000 .

2 J.A. Downie, 'Marlowe: facts and fictions', in J.A. Downie and J.T. Parnell (edd.), Constructing Christopher Marlowe (Cambridge, 2000; paperback edn., 2006), 13-29.

${ }^{3}$ M.J. Trow and Taliesin Trow, Who Killed Kit Marlowe? A Contract to Murder in Elizabethan England (Stroud, 2001).

${ }^{4}$ D. Riggs, 'The Killing of Christopher Marlowe', Stanford Humanities Review, 8 (2000), 239: 'My interpretation of the killing is much simpler and goes like this: at a time when
} 
Queen Elizabeth and her Privy Council were cracking down on disobedient subjects, Marlowe gave offense; and the Queen, in turn, made him pay'. Professor Riggs offers a similar interpretation in The World of Christopher Marlowe (London, 2004), according to which 'Queen Elizabeth gave the order to "prosecute ... to the full"' the suggestion contained in the Baines note 'that the mouth of so dangerous a member may be stopped' (330). 'The facts surrounding Marlowe's death', Riggs continues, 'suggest that ... all the relevant evidence leads back to the Palace' (334).

${ }^{5}$ C. Nicholl, The Reckoning: The Murder of Christopher Marlowe (rev. edn., London, 2002).

${ }^{6}$ R. Kendall, Christopher Marlowe and Richard Baines: Journeys through the Elizabethan Underground (Madison and London, 2003), 279, 255, 281.

${ }^{7}$ See P. Honan, Christopher Marlowe: Poet \& Spy (Oxford, 2005), 402-3.

${ }^{8}$ Honan, Christopher Marlowe, 1, 3, 106. Examples of Professor Honan writing about what Marlowe 'may have' or 'would have' known are ubiquitous, but the formulations 'must have' and 'would have' both occur on p. 106.

${ }^{9}$ C. B. Kuriyama, Christopher Marlowe: A Renaissance Life (Ithaca and London, 2002), 6.

${ }^{10}$ C.F. Tucker Brooke, The Life of Marlowe and the Tragedy of Dido Queen of Carthage (London, 1930), 33. The supplicat, signed by Robert Norgate, the Master of Corpus Christi, and by Henry Ruse, tutor, was made in the usual form: 'Supplicat reverentiis vestris Christopherus Marley, ut novem termini completi Corp. (post finalem eius determinationem) in quibus lectiones ordinarias audivit (licet non omnino secundum formam statutu) una cum omnibus oppositionibus responsionibus caeterisque exercitiis 
per statuta regia requisitis sufficiant ei ad incipiendum in artibus'. It is printed, along with the following translation, in Kuriyama, Christopher Marlowe, 201-2: 'Christopher Marley prays your honours that, having completed nine terms (after his final disputation), in which he heard the regular lectures (not all of them, as permitted according to the statute), together with all the opponencies, responsions, and other exercises required by the royal statutes, they may suffice for him to commence in arts'.

${ }^{11}$ These are preserved at Corpus Christi College, Cambridge, in a MS volume (entitled ‘Audits \&c. 1575 to 90 ’ on the original spine).

12 John Bakeless, The Tragicall History of Christopher Marlowe 2 vols (Cambridge, MA, 1942), 1,75 .

${ }^{13}$ All quotations from the Privy Council certificate follow Acts of the Privy Council, 1542-1604, edited by J.R. Dasent, 32 vols (London, 1890-1907), xv. 141.

${ }^{14}$ In addition to Professor Honan's Christopher Marlowe, which includes two chapters entitled 'Into espionage' and 'A spy abroad', respectively, he is described thus, inter alia, in C. Nicholl, The Reckoning: The Murder of Christopher Marlowe (London, 1991), 266 (p. 328 in the rev. edn.) (Unless otherwise indicated, and in an attempt to avoid confusion, subsequent references to Mr. Nicholl's book are to the first edition, rather than to the 'Revised Edition'. However, all the passages quoted in my essay are to be found in both editions.)

${ }^{15}$ Kuriyama, Christopher Marlowe, 70.

${ }^{16}$ Nicholl, The Reckoning, 92.

${ }^{17}$ Nicholl, The Reckoning, 93. 
${ }^{18}$ G.C. Moore Smith, 'Marlowe at Cambridge', Modern Language Review, 4 (1909), 177.

${ }^{19}$ Kuriyama, Christopher Marlowe, 2-3.

${ }^{20}$ Kuriyama, Christopher Marlowe, 70.

${ }^{21}$ Trow and Trow, Who Killed Kit Marlowe?, 60, 67.

${ }^{22}$ According to the Trows, the phrase 'was determined' in the Privy Council letter 'is merely Elizabethan speak for "was ordered"' (Trow and Trow, Who Killed Kit Marlowe?, 67). It seems likely that the Trows' confidence that Marlowe travelled to the continent stems from Alan Haynes' assumption that Marlowe's first task was 'to spy on the embassy' at Paris. Mr. Haynes offers no evidence for his assertion. See Haynes, The Elizabethan Secret Services, 109, and Honan, Christopher Marlowe, 150-1.

${ }^{23}$ Kuriyama, Christopher Marlowe, 71.

${ }^{24}$ Nicholl, The Reckoning, 98.

${ }^{25}$ Nicholl, The Reckoning, 192, 191.

${ }^{26}$ Nicholl, The Reckoning, 201.

${ }^{27}$ The National Archive, S.P. 84/44, fol. 60, first published in R.B. Wernham, 'Christopher Marlowe at Flushing in 1592', English Historical Review, 91 (1976), 344345.

${ }^{28}$ Interestingly, Marlowe's successor to the Parker scholarship, Jacob Bridgeman, was not formally elected 'in locum domini Marley’ until 10 November 1587.

${ }^{29}$ P. Roberts, 'The "Studious Artizan": Christopher Marlowe, Canterbury and Cambridge', in D. Grantley and P. Roberts (edd.), Christopher Marlowe and English Renaissance Culture (Aldershot, 1996), 25. 
${ }^{30}$ See Kuriyama, Christopher Marlowe, 201-202.

${ }^{31}$ Although there is some uncertainty about the exact provisions of the Parker scholarships, the following details can be derived from the extent documents: Marlowe appears to have arrived at Corpus Christi in early December 1580; he received his first weekly stipend in the last week of December; he matriculated on 17 March 1581; he was formally elected to his scholarship on 7 May 1581; he received his final payment from his scholarship in March 1587; and his successor as Parker scholar was elected in November 1587.

${ }^{32}$ R. Kendall, 'Richard Baines and Christopher Marlowe's Milieu', English Literary Renaissance, 24 (1994), 551-2; cf. Kuriyama, Christopher Marlowe, 64-69.

${ }^{33}$ Roberts, "The "Studious Artizan", 27, 36 n. 33.

${ }^{34}$ British Library Harleian MS 6848, fols. 185-6.

${ }^{35}$ British Library, Harleian MS 6848, fol. 154; Harleian MS 6849, fols. 218-9.

${ }^{36}$ British Library, Harleian MS 6853, fols. 307-8.

${ }^{37}$ The letter, first published by S.E. Sprott in 'Drury and Marlowe', TLS, 2 August 1974, p. 840, is preserved in Lambeth Palace Library (LP MS 649, fol. 246). Drury does not assign a year to his letter, merely dating it 'the first August'. It is, however, endorsed ' 1593 ' in a different hand. Scholars, from Sprott onwards, have assumed that the endorsement is contemporary.

${ }^{38}$ British Library, Harleian MS 6848, fols. 190-1.

${ }^{39}$ I owe this peculiarly apposite term to a private communication from Professor Constance Brown Kuriyama.

${ }^{40}$ Nicholl, The Reckoning, 289. 
${ }^{41}$ BL Harleian MS 6849, fol. 218.

42 Ibid.

${ }^{43}$ Dasent (ed.), Acts of the Privy Council, xxiv. 222.

${ }^{44}$ BL Harleian MS 6849, fol. 218.

${ }^{45}$ Nicholl, The Reckoning, 42.

${ }^{46}$ Stanley Wells (ed.), Robert Greene, Perymedes the Blacksmith and Pandosto (New York and London, 1988), 106.

${ }^{47}$ Curtis C. Breight, "'Drama in Words": The Drama and Assassination of Christopher Marlowe', in id., Surveillance, Militarism and Drama in the Elizabethan Era (Basingstoke and New York, 1996), 156.

${ }^{48}$ Arthur Freeman, 'Marlowe, Kyd, and the Dutch Church Libel', English Literary Renaissance, 3 (1973), 50-51.

${ }^{49}$ Nicholl, The Reckoning, 60-64.

${ }^{50}$ Ethel Seaton, 'Marlowe, Robert Poley, and the Tippings', Review of English Studies, 5 (1929), 274.

${ }^{51}$ Nicholl, The Reckoning, 287-8. Writing about these matters in the Revised Edition of his book, Mr. Nicholl suggests that: 'They precede, and no doubt cause, the summoning of Marlowe by the Privy Council on 18 May' (Nicholl, The Reckoning, rev edn., 356).

${ }^{52}$ British Library Harleian MS 6848, fols. 187-9.

${ }^{53}$ The National Archive, S.P. 84/44, fol. 60, cited Wernham, 'Christopher Marlowe at Flushing in 1592', 344-5. Extended consideration of the identity of Richard Baines, together with an account of the way in which scholarly opinions on the subject have evolved, is offered in Kendall, Christopher Marlowe and Richard Baines, 30-34. 
${ }^{54}$ British Library Harleian MS 6848, fols. 185-6.

${ }^{55}$ Sidney sent Baines, Marlowe and Gilbert 'over unto [Burleigh], to take their trial as you shall think best'. Interestingly, we do not know what happened to Marlowe once he arrived in England.

${ }^{56}$ Nicholl, The Reckoning, 310-311.

${ }^{57}$ British Library, Harleian MS 6848, fols. 185-6.

${ }^{58}$ British Library, Harleian MS 6853, fols. 307-8.

${ }^{59}$ Kuriyama, Christopher Marlowe, 222.

${ }^{60}$ British Library, Harleian MS 6848, fols. 190-1. The typographical arrangements of Professor Kuriyama's transcription of what she describes as 'a letter concerning Cholmeley' is potentially misleading in that the (torn) endorsement, ' $\mathrm{Y}$ e atheisme of [Cholmeley] \& others', appears not at the beginning of the document, but on its own right at the end, on the verso of fol. 191. Fol. $190^{\mathrm{r}}$ is headed 'Remembrannces of wordes \& matter againste Ric Cholmeley'.

${ }^{61}$ Nicholl, The Reckoning, 306. Dr Kendall's assertion that 'the process of sealing every last crack' undertaken in his Christopher Marlowe and Richard Baines makes the case for Drury's authorship of the 'Remembrannces' 'for all intents and purposes, completely watertight' (255), is cited with approval by Professor Riggs in The World of Christopher Marlowe (374).

${ }^{62}$ Kuriyama, Christopher Marlowe, 150, 215. Professor Honan accepts Professor Kuriyama's argument that Drury's authorship of the 'Remembrannces' 'is impossible' (Honan, Christopher Marlowe, 338).

${ }^{63}$ Seaton, 'Marlowe, Robert Poley, and the Tippings', 285-6. 
${ }^{64}$ British Library, Harleian MS 6848, fol. $190^{\mathrm{r}}$.

${ }^{65}$ British Library, Harleian MS 7002, fol. 10.

${ }^{66}$ Seaton, 'Marlowe, Robert Poley, and the Tippings', 285-6, 287.

${ }^{67}$ Nicholl, The Reckoning, 312.

${ }^{68}$ Kuriyama, Christopher Marlowe, 132.

${ }^{69}$ It is for this reason, one assumes, that Professor Honan asserts that the Baines note 'reached the Council by Saturday evening, 26 May' (Honan, Christopher Marlowe, 338).

${ }^{70}$ British Library, Harleian MS 6853, fols. 307-8.

${ }^{71}$ Kuriyama, Christopher Marlowe, 131. Professor Honan seems to agree. 'Shortly after Marlowe's death', he writes, 'someone did make a hastily edited copy of Baines's Note for the queen' (Honan, Christopher Marlowe, 339).

${ }^{72}$ British Library, Harleian MS 6849, fol. 218.

${ }^{73}$ Lambeth Palace Library, LP MS 649, fol. 246.

${ }^{74}$ Nicholl, The Reckoning, 311.

${ }^{75}$ Nicholl, The Reckoning, 304.

${ }^{76}$ Nicholl, The Reckoning, 304-5. Mr. Nicholl's conclusions are paraphrased and accepted in their entirety in Professor Riggs's The World of Christopher Marlowe, 321. While noting that 'Drury does not explicitly refer to Marlowe', Professor Honan observes that 'Drury hints that he had discovered the identity of the Dutch Church libeller'. He does not, however, accept the attribution of the 'Remembrannces' to Drury, and he points out that: 'There is no historical evidence of any kind that Queen Elizabeth personally had anything to do with Marlowe's fate' (Honan, Christopher Marlowe, 340, 338, 339).

${ }^{77}$ Kendall, Christopher Marlowe and Richard Baines, 261, 260. 
${ }^{78}$ Riggs, The World of Christopher Marlowe, 320, 321, 326.

${ }^{79}$ Kuriyama, Christopher Marlowe, 146.

${ }^{80}$ Kuriyama, Christopher Marlowe, 146.

${ }^{81}$ Riggs, The World of Christopher Marlowe, 1. None of the references cited by

Professor Riggs (on p. 351) convincingly documents his opening statement. In what sense the Queen 'was said to have pronounced' Marlowe's death sentence 'at court' I do not know, although the phrase 'prosecute it to the full' is clearly derived from the Drury letter ${ }^{82}$ Kuriyama, Christopher Marlowe, 78.

${ }^{83}$ Professor Honan links the killing of Marlowe to Frizer's 'desire to foster a cash source'. Representing him as Thomas Walsingham's 'business agent', he argues that Frizer 'stood to gain from a rich and varied flow of benefits which could accrue to Thomas, if no albatross hung around his master's neck'. According to this interpretation, the albatross was Marlowe, under investigation for atheism, and therefore 'an intolerable, ruinous, and deadly burden for anyone who hoped to profit at Scadbury'. For this reason, Professor Honan assumes that Frizer 'killed to remove an obstacle which imperilled his profits' (Honan, Christopher Marlowe, 349, 355). Such an interpretation, needless to say, is intuitive and cannot be documented.

${ }^{84}$ Breight, “"Drama in Words”: The Drama and Assassination of Christopher Marlowe', $131,128$.

${ }^{85}$ Kuriyama, Christopher Marlowe, 137. 